Article

\title{
Design and Crystal Structures of Two New Compounds Fused with 3,4,5-Trimethoxybenzyl Group and 6,10-Dioxaspiro Group
}

\author{
Wulan Zeng * (D), Xia Wang and Jinhe Jiang * \\ Department of Chemistry, Chemical Engineering and Environmental Engineering, Weifang University, \\ Weifang 261061, China; wangxia-2001@163.com \\ * Correspondence: wulanzeng@163.com (W.Z.); jiangjinhe2006@163.com (J.J.); Tel.: +86-536-8785802 (W.Z. \& J.J.) \\ Received: 7 March 2018; Accepted: 15 March 2018; Published: 23 March 2018

\begin{abstract}
Two new compounds, 8-(3,4,5-trimethoxybenzylidene)-6,10-dioxaspiro[4,5]decane-7,9-dione (J1) and 8-(3,4,5-trimethoxybenzyl)-6,10-dioxaspiro[4,5]decane-7,9-dione (J2) have been designed and generated by the reaction of 3,4,5-trimethoxybenzaldehyde with 6,10-dioxaspiro[4,5]decane-7,9-dione in different solvents. The 3,4,5-trimethoxybenzyl group of the two compounds connects with the dioxaspiro group via double bond (J1) and single bond (J2), respectively. The crystal structure determinations show that Compound J1 belongs to the triclinic system, space group P-1 with $\mathrm{a}=5.4056(11) \AA, \mathrm{b}=11.465(2) \AA, \mathrm{c}=13.502(3) \AA, \alpha=92.06(3)^{\circ} \AA, \beta=91.35(3)^{\circ}, \gamma=93.50(3)^{\circ}$, $\mathrm{C}_{18} \mathrm{H}_{20} \mathrm{O}_{7}, \mathrm{Mr}=348.34, \mathrm{~V}=834.4(3) \AA^{3}, \mathrm{Z}=2, \mathrm{Dc}=1.386 \mathrm{~g} / \mathrm{cm}^{3}, \mathrm{~F}(000)=368$. Compound J2 is also of the triclinic system, space group P-1 with $a=8.8778(18) \AA, b=9.5285(19) \AA$, c $=11.082(4)$ $\AA, \alpha=89.69(3)^{\circ}, \beta=67.38(3)^{\circ}, \gamma=81.68(3)^{\circ}, \mathrm{C}_{18} \mathrm{H}_{22} \mathrm{O}_{7}, \mathrm{Mr}=250.36, \mathrm{~V}=854.9(3) \AA^{3}, \mathrm{Z}=2$, $\mathrm{Dc}=1.361 \mathrm{~g} / \mathrm{cm}^{3}, \mathrm{~F}(000)=372$. Both compounds form three-dimensional network structures via $\mathrm{C}-\mathrm{H} \cdots \mathrm{O}$ intra- and intermolecular hydrogen bonds.
\end{abstract}

Keywords: synthesis; crystal structure; 3,4,5-trimethoxybenzyl group; 6,10-dioxaspiro[4,5]decane-7,9-dione

\section{Introduction}

The design and synthesis of compounds containing the spiro ring framework have received much attention owing to their wide applications in medicine. For example, spiro-iminosugars with 1,2,3-triazole have shown glycosidase inhibitory activity as well as antifungal activity [1]. Spiro-oxindoles were identified as anti-breast cancer and potent antiproliferative agents [2-4]. Spirombandakamines possess strong antiprotozoal activity [5]. Spiro-thiazine derivatives act as antimycobacterial activity [6]. Recently, spiro compounds have also drawn much attention due to diverse applications in organic functional materials such as circularly polarized luminescence (CPL) materials [7], a new rhodamine-based chemosensor [8], organic light emitting diodes (OLEDs) [9], a high-performance electrophosphorescent device [10], a fluorescent switch [11], optical data storage [12], and so on.

For these reasons, for 10 years, our group has exploited several approaches to synthesize all kinds of spiro compounds [13-16]. In continuation of our work, two new compounds: 8-(3,4,5-trimethoxybenzylidene)-6,10-dioxaspiro[4,5]decane-7,9-dione (J1) and 8-(3,4,5trimethoxybenzyl)-6,10-dioxaspiro[4,5]decane-7,9-dione (J2) have been prepared via different synthetic routes (Scheme 1). In comparison to our previously synthetic route of Compound J1, Compound J2 was linked via single bond instead of double bond. In addition, their structures are also characterized by elemental analysis, IR, ${ }^{1} \mathrm{H}$ and ${ }^{13} \mathrm{C}$ NMR analysis, and single-crystal $\mathrm{X}$-ray diffraction. 


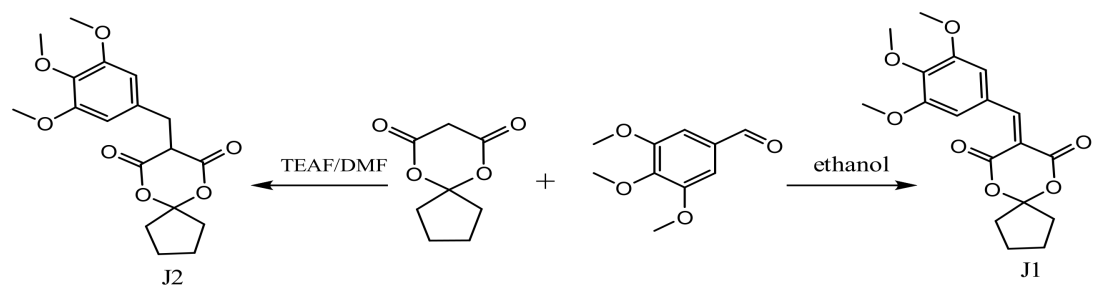

Scheme 1. Synthetic routes of $\mathbf{J 1}$ and $\mathbf{J} 2$.

\section{Materials and Methods}

\subsection{Physical Measuremints}

The IR spectra were recorded as $\mathrm{KBr}$ pellets with a Nicolet FT-IR 510P Spectrometer (Nicolet Instrument Inc., Madison, WI, USA). The analyses of C, H, and N were made on an Elementar Vario EL III elemental analyzer (Elementar, Hanau, Germany). $1 \mathrm{H}$ NMR and ${ }^{13} \mathrm{C}$ NMR spectra were recorded on a Bruker Avance-500 spectrometer (Bruker, Elisabethhof, The Netherlands) with $\mathrm{CD}_{3} \mathrm{COCD}_{3}$ as the solvent. X-ray diffraction for Compounds $\mathbf{J} \mathbf{1}$ and $\mathbf{J} \mathbf{2}$ were performed on a Spider diffractometer (Rigaku, Tokyo, Japan).

\subsection{Preparation of $\mathbf{J} \mathbf{1}$ and $\mathbf{J} \mathbf{2}$}

J1 is easily obtained by a literature known method [14]. A $100 \mathrm{~mL}$ round-bottomed flask was charged with 3,4 5-trimethoxybenzaldehyde $(0.98 \mathrm{~g}, 5 \mathrm{~mL}), 6,10$-dioxaspiro[4,5]decane-7,9-dione $(0.85 \mathrm{~g}$, $5 \mathrm{~mL})$, and ethanol $(15 \mathrm{~mL})$. The mixture was stirred and refluxed for $2.5 \mathrm{~h}$, and the solution was then cooled to generate the precipitate. Yield 31.3\%, m.p.: 96.9 98. ${ }^{\circ} \mathrm{C}$. Anal. Calcd. for $\mathrm{C}_{18} \mathrm{H}_{20} \mathrm{O}_{7}$ : $\mathrm{C}, 62.06$; $\mathrm{H}, 5.79$; Found: $\mathrm{C}, 62.18 ; \mathrm{H}, 5.68 .{ }^{1} \mathrm{H}$ NMR $\left(500 \mathrm{MHz}, \mathrm{CD}_{3} \mathrm{OCD}_{3}\right): 7.65(\mathrm{~s}, 2 \mathrm{H}, \mathrm{Ar}-\mathrm{H}), 8.19(\mathrm{~s}, 1 \mathrm{H}$, $=\mathrm{CH}-), 3.83\left(\mathrm{~s}, 9 \mathrm{H},-\mathrm{OCH}_{3}\right), 2.0 \sim 2.15(\mathrm{~m}, 4 \mathrm{H}$, cyclopentane-H), 1.77 1.80 (s, 4H, cyclopentane $-\mathrm{H})$. ${ }^{13} \mathrm{C}$ NMR $\left(500 \mathrm{MHz}, \mathrm{CD}_{3} \mathrm{OCD}_{3}\right): \delta=22.9\left(\mathrm{CH}_{2}, \mathrm{C} 16 / \mathrm{C} 17\right.$, cyclopentane), $29.01\left(\mathrm{CH}_{2}, \mathrm{C} 15 / \mathrm{C} 18\right.$, cyclopentane), $55.7\left(\mathrm{CH}_{3}, \mathrm{C} 1 / \mathrm{C} 3\right.$, trimethoxybenzyl ring), $78.32\left(\mathrm{CH}_{3}, \mathrm{C} 2\right.$, trimethoxybenzyl ring), $106.57(\mathrm{CH}, \mathrm{C} 7 / \mathrm{C}$, trimethoxybenzyl ring), 112.24 (C, C14, 1,3-dioxane ring) 114.39 (C, C12, 1,3-dioxane ring), 126.9 (C, C8, trimethoxybenzyl ring), 143.37 (C, C5 trimethoxybenzyl ring), 152.73 (C, C4/C6 trimethoxybenzyl ring), $156.63(\mathrm{CH}, \mathrm{C10},=\mathrm{CH}-), 163.72(\mathrm{C}, \mathrm{C} 11 / \mathrm{C} 13,1,3$-dioxane ring). Evaporation of a solution in petroleum ether/ethyl acetate $(2: 1=v / v)$ at room temperature yielded yellow crystals of 8-(3,4,5-trimethoxybenzylidene)-6,10-dioxaspiro[4,5]decane-7,9-dione (J1).

A solution of TEAF was prepared dropwise adding triethylamine $(40 \mathrm{~mL})$ to methanoic acid $(10 \mathrm{~mL})$. A $100 \mathrm{~mL}$ round-bottomed flask was charged with 3,4,5-trimethoxybenzaldehyde $(0.98 \mathrm{~g}$, $5 \mathrm{~mL}), 6,10$-dioxaspiro[4,5]decane-7,9-dione $(0.85 \mathrm{~g}, 5 \mathrm{~mL}), \operatorname{TEAF}(5 \mathrm{~mL})$, and DMF $(5 \mathrm{~mL})$. The mixture was stirred at room temperature for half an hour and was then heated at $50{ }^{\circ} \mathrm{C}$ for $12 \mathrm{~h}$. After the mixture was cooled to room temperature and water was added $(15 \mathrm{~mL})$, the solution was placed at $5 \sim 10{ }^{\circ} \mathrm{C}$ for another $16 \mathrm{~h}$. The precipitate was washed twice with ethanol $(12 \mathrm{~mL})$ and three times with water and dried. Yield 18.5\%. m.p.: $134.9-135.9^{\circ} \mathrm{C}$. Anal. Calcd. For $\mathrm{C}_{18} \mathrm{H}_{22} \mathrm{O}_{7}: \mathrm{C}, 61.71 ; \mathrm{H}, 6.33$. Found: C, 61.63; H, 6.35. ${ }^{1} \mathrm{H}$ NMR (500 MHz, $\left.\mathrm{CD}_{3} \mathrm{OCD}_{3}\right)$ : $7.14(\mathrm{~s}, 2 \mathrm{H}, \mathrm{Ar}-\mathrm{H}), 3.22\left(\mathrm{~s}, 2 \mathrm{H},-\mathrm{CH}_{2}-\right)$, $3.67(\mathrm{~s}, 1 \mathrm{H}, 1,3-$ dioxane ring- $\mathrm{H}), 4.27\left(\mathrm{~s}, 9 \mathrm{H},-\mathrm{OCH}_{3}\right), 2.04 \sim 2.31(\mathrm{~m}, 4 \mathrm{H}$, cyclopentane- $\mathrm{H}), 1.74 \sim 1.82$ (s, $4 \mathrm{H}$, cyclopentane-H). ${ }^{13} \mathrm{C}$ NMR $\left(500 \mathrm{MHz}, \mathrm{CD}_{3} \mathrm{OCD}_{3}\right): \delta=22.3\left(\mathrm{CH}_{2}, \mathrm{C} 16 / \mathrm{C} 17\right.$, cyclopentane), $23.83\left(\mathrm{CH}_{2}, \mathrm{C} 10,-\mathrm{CH}_{2}-\right), 28.9\left(\mathrm{CH}_{2}, \mathrm{C} 15 / \mathrm{C} 18\right.$, cyclopentane $), 49.1(\mathrm{CH}, \mathrm{C} 12,1,3$-dioxane ring), $55.6\left(\mathrm{CH}_{3}, \mathrm{C} 1 / \mathrm{C} 3\right.$, trimethoxybenzyl ring $), 78.3\left(\mathrm{CH}_{3}, \mathrm{C} 2\right.$, trimethoxybenzyl ring), $113.72(\mathrm{C}, \mathrm{C} 14$, 1,3-dioxane ring), $115.1(\mathrm{CH}, \mathrm{C} 7 / \mathrm{C} 9$, trimethoxybenzyl ring), 129.7 (C, $\mathrm{C} 8$, trimethoxybenzyl ring), 131.94 (C, C5, trimethoxybenzyl ring), 156.7 (C, C4/C6 trimethoxybenzyl ring), 170.12 (C, C11/C13, 1,3-dioxane ring). The evaporation of a solution in petroleum ether/ethyl acetate $(4: 1=v / v)$ yielded yellow crystals of 8-(3,4,5-trimethoxybenzyl)-6,10-dioxaspiro[4,5]decane-7,9-dione (J2). 


\subsection{Crystallography}

The X-ray data of the two compounds were collected on Rigaku Spider Rapid IP area detector at 293(2) K. The structure of the two compounds was determined by SHELXL-97 and SHELXT-97 [17]. The final cycle of refinement gave $R=0.0651$ and $w R=0.1847(R=0.0578$ and $w R=0.1682$ for J2) with $w=1 /\left(\sigma^{2}\left(F_{o}{ }^{2}\right)+(0.1185 P)^{2}+0.1481 P\right)\left(w=1 /\left(\sigma^{2}\left(F_{o}{ }^{2}\right)+(0.1213 P)^{2}+0.0698 P\right)\right.$ for $\left.\mathbf{J} 2\right)$, where $P=\left(F_{o}{ }^{2}+2 F_{c}{ }^{2}\right) / 3$. The key parameters of $\mathbf{J} \mathbf{1}$ and $\mathbf{J} \mathbf{2}$ are summarized in Table 1 . Crystallographic data for the structures reported in this paper have been deposited with the Cambridge Crystallographic Data Centre as supplementary publication No. CCDC-1567472 and CCDC-1567470. Copies of available material can be obtained, free of charge, on application to the Director, CCDC, 12 Union Road, Cambridge CB2 1EZ, UK (Fax: 44-(0)-1223-336033 or e-mail: deposit@ccdc.cam.ac.uk).

Table 1. The key parameters for $\mathbf{J 1}$ and $\mathbf{J} 2$.

\begin{tabular}{|c|c|c|}
\hline Compounds & $\mathrm{J} 1$ & $\mathrm{~J} 2$ \\
\hline Formula & $\mathrm{C}_{18} \mathrm{H}_{20} \mathrm{O}_{7}$ & $\mathrm{C}_{18} \mathrm{H}_{22} \mathrm{O}_{7}$ \\
\hline CCDC No. & 1567472 & 1567470 \\
\hline Color/shape & red/block & Red/needle \\
\hline $\mathrm{Mr}$ & 348.34 & 350.36 \\
\hline Crystal System, Space group & Triclinic, P-1 & Triclinic, P-1 \\
\hline 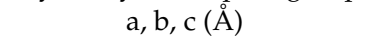 & $5.4056(11), 11.465(2), 13.502(3)$ & $8.8778(18), 9.5285(19), 11.082(2)$ \\
\hline$\alpha, \beta, \gamma\left({ }^{\circ}\right)$ & 92.06(3), 91.35(3), 93.50(3) & $89.69(3), 67.38(3), 81.68(3)$ \\
\hline Crystal Size (mm) & $0.24 \times 0.16 \times 0.12$ & $0.14 \times 0.10 \times 0.06$ \\
\hline Wavelength $(\AA)$ & 0.71073 & 0.71073 \\
\hline$\theta$ Ranges $\left({ }^{\circ}\right)$ & $3.02-27.48$ & $3.02-27.48$ \\
\hline $\mathrm{V}\left(\AA^{3}\right)$ & $3135.5(2)$ & $854.9(3)$ \\
\hline $\mathrm{Z}$ & 2 & 2 \\
\hline $\mathrm{F}(000)$ & 368 & 372 \\
\hline $\mathrm{D} / \mathrm{g} \cdot \mathrm{cm}^{-3}$ & 1.386 & 1.361 \\
\hline$\mu / \mathrm{mm}^{-1}$ & 0.107 & 0.105 \\
\hline$-\mathrm{h}, \mathrm{h} /-\mathrm{k}, \mathrm{k} /-\mathrm{l}, \mathrm{l}$ & $-7: 6 ;-14: 14 ;-17: 17$ & $-11: 11 ;-10: 12 ;-14: 14$ \\
\hline $\begin{array}{l}\text { Total, unique and }[\mathrm{I}>2 \sigma(\mathrm{I})] \\
\text { reflections }\end{array}$ & $8107,3785,1786$ & $8389,3894,2870$ \\
\hline $\begin{array}{c}\text { No. of reflections, restraints, } \\
\text { parameters }\end{array}$ & $3785,0,226$ & $3894,0,226$ \\
\hline $\mathrm{R}$ (int) & 0.0312 & 0.0261 \\
\hline$R, w R, \mathrm{~S}$ & $0.0651,0.1847,1.129$ & $0.0578,0.1682,1.105$ \\
\hline$(\Delta \rho)_{\max }(\Delta \rho)_{\min }\left(\mathrm{e} / \AA^{3}\right)$ & $0.595,-0.427$ & $0.630,-0.334$ \\
\hline
\end{tabular}

\section{Results and Discussion}

\subsection{Crystal Structures}

Selected bond lengths and angles of the two compounds are listed in Table 2. The molecular structures of $\mathbf{J} \mathbf{1}$ and $\mathbf{J} \mathbf{2}$ are shown in Figure 1. Packing arrangement in the unit cell of $\mathbf{J} \mathbf{1}$ and $\mathbf{J} \mathbf{2}$ are displayed in Figure 2, respectively.
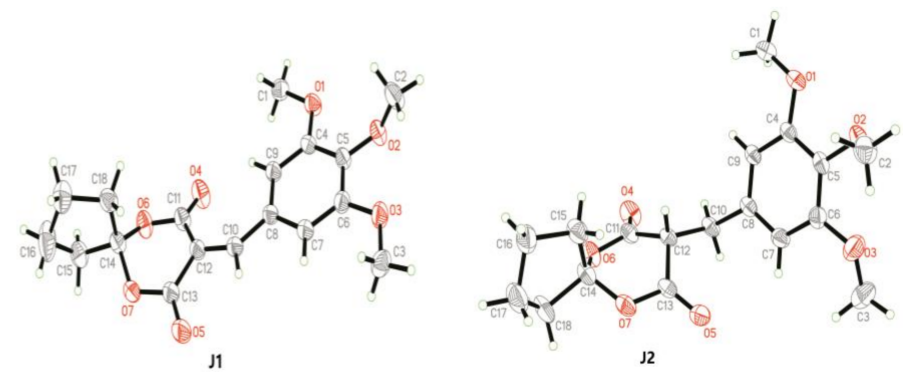

Figure 1. The molecular structures of $\mathbf{J 1}$ and $\mathbf{J} 2$ with an atomic numbering scheme. 
Table 2. Selected bond lengths $(\AA)$ and bond angles $\left(^{\circ}\right)$ of $\mathbf{J 1}$ and $\mathbf{J} 2$.

\begin{tabular}{ccc}
\hline & J1 & J2 \\
\hline Bond & Dist. & Dist. \\
$\mathrm{C}(8)-\mathrm{C}(10)$ & $1.445(4)$ & $1.516(2)$ \\
$\mathrm{C}(10)-\mathrm{C}(12)$ & $1.359(4)$ & $1.535(2)$ \\
$\mathrm{C}(8)-\mathrm{C}(7)$ & $1.407(4)$ & $1.380(3)$ \\
$\mathrm{C}(9)-\mathrm{C}(8)$ & $1.394(4)$ & $1.391(2)$ \\
$\mathrm{O}(4)-\mathrm{C}(11)$ & $1.206(4)$ & $1.193(2)$ \\
$\mathrm{O}(5)-\mathrm{C}(13)$ & $1.197(4)$ & $1.199(2)$ \\
\hline Angle & $\left(^{\circ}\right)$ & $\left(^{\circ}\right)$ \\
$\mathrm{C}(12)-\mathrm{C}(10)-\mathrm{C}(8)$ & $137.3(3)$ & $114.13(13)$ \\
$\mathrm{C}(9)-\mathrm{C}(8)-\mathrm{C}(7)$ & $119.1(3)$ & $119.28(15)$ \\
$\mathrm{C}(9)-\mathrm{C}(8)-\mathrm{C}(10)$ & $126.7(3)$ & $122.19(15)$ \\
$\mathrm{C}(7)-\mathrm{C}(8)-\mathrm{C}(10)$ & $114.2(2)$ & $118.51(16)$ \\
$\mathrm{C}(10)-\mathrm{C}(12)-\mathrm{C}(13)$ & $128.22(15)$ & $109.48(13)$ \\
$\mathrm{C}(10)-\mathrm{C}(12)-\mathrm{C}(11)$ & $114.83(14)$ & $113.71(15)$ \\
$\mathrm{C}(13)-\mathrm{C}(12)-\mathrm{C}(11)$ & $116.91(14)$ & $112.53(13)$ \\
\hline
\end{tabular}
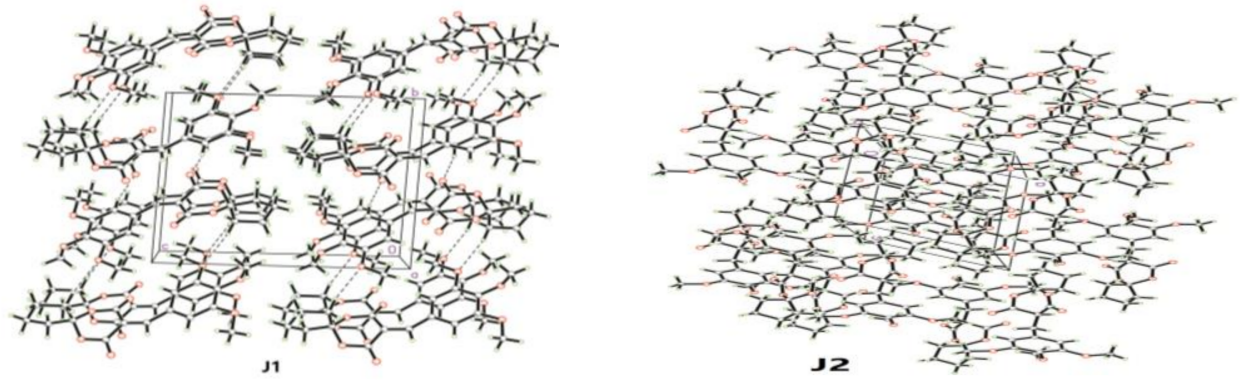

Figure 2. Perspective views of three-dimensional packing structures of $\mathbf{J 1}$ and J2.

As can be seen from Figure 1, two compounds both comprise the 3,4,5-trimethoxybenzyl group and the dioxaspiro group. From the bond length data, the C10-C12 bond length of 1.535(2) $\AA$ (J2) is longer that of 1.359(4) (J1), which indicates that the 3,4,5-trimethoxybenzyl group connects with the dioxaspiro group by the central C(10) atoms via double bond (J1) and single bond (J2), respectively. At the same time, the $\mathrm{C} 8-\mathrm{C} 10$ bond lengths of $1.516(2)(\mathrm{J} 2)$ and $1.445(4)(\mathrm{J} 1) \AA$ are also typical of a C-C single bond. The $\mathrm{C}(12)-\mathrm{C}(10)-\mathrm{C}(8)$ bond angle of $114.13(13)^{\circ}(\mathrm{J} 2)$ is smaller than that of $137.3(3)^{\circ}(\mathbf{J 1})$, which is in agreement with similar structures $\left(137.76(2)^{\circ}\right.$ and $\left.129.67(2)^{\circ}\right)$ [14]. The double bond lengths of the 1,3-dioxane ring in $\mathrm{J} 1(\mathrm{O}(4)-\mathrm{C}(11) 1.206(4) \AA, \mathrm{O}(5)-\mathrm{C}(13)$, and 1.197(4) $\AA$ ) are similar to those of J2 (O(4)-C(11) 1.193(2) $\AA, \mathrm{O}(5)-\mathrm{C}(13)$, and 1.199(2) $\AA$ ). In J1, the five atoms (C8 and C10-C13) are fairly planar, (plane equation: $-3.0923 \mathrm{x}-7.7068 \mathrm{y}-5.0336 \mathrm{z}=5.6522$ ), with a maximum deviation from the mean plane of $0.016 \AA$. However, the five atoms (C8, C10-C13) of $\mathbf{J} 2$ are not planar. The dihedral angle of the plan (C4-C10) and the plan (O4, O6, C11, and C12) is $16.39^{\circ}(\mathrm{J} 1)$ and $61.51(9)^{\circ}$ (J2), respectively.

Table 3 shows that the two compounds both comprise some $\mathrm{C}-\mathrm{H} \cdots \mathrm{O}$ intra- and intermolecular hydrogen bonds. The main difference of them is $\mathrm{C}(9)-\mathrm{H}(9 \mathrm{~A}) \cdots \mathrm{O}(4)$ hydrogen bonds. The intramolecular hydrogen bands of $\mathbf{J 1}$ occurs at $\mathrm{C}(9)-\mathrm{H}(9 \mathrm{~A}) \cdots \mathrm{O}(4)$, and the donor and acceptor distances are 2.9287(2) ^. However, the intermolecular hydrogen bands of J2 occurs at $\mathrm{C}(9)-\mathrm{H}(9 \mathrm{~A}) \cdots \mathrm{O}(4)$, and the donor and acceptor distances are 3.170(2) $\AA$, with symmetry codes $1-\mathrm{x}$, $-1-\mathrm{y}, 1-\mathrm{z}$, which is in accord with their structures. All above hydrogen bonds generate the three-dimensional network structures of both compounds (Figure 2). 
Table 3. Intra- and intermolecular hydrogen bond in $\mathbf{J 1}$ and $\mathbf{~} \mathbf{2}$.

\begin{tabular}{cccccc}
\hline $\mathbf{D}-\mathbf{H} \cdots \mathbf{A}$ & Symmetry & $\mathbf{D}-\mathbf{H}(\mathbf{A})$ & $\mathbf{H} \cdots \mathbf{A}(\mathbf{A})$ & $\mathbf{D} \cdots \mathbf{A}(\mathbf{A})$ & $\left\langle\mathbf{D}-\mathbf{H} \cdots \mathbf{A}\left({ }^{\circ}\right)\right.$ \\
\hline $\mathrm{C}(2)-\mathrm{H}(2 \mathrm{~B}) \cdots \mathrm{O}(3)(\mathbf{J 1})$ & intra & 0.9600 & 2.4481 & $3.0097(2)$ & 117.13 \\
$\mathrm{C}(9)-\mathrm{H}(9 \mathrm{~A}) \cdots \mathrm{O}(4)(\mathbf{J} 1)$ & intra & 0.9300 & 2.1532 & $2.9287(2)$ & 140.18 \\
$\mathrm{C}(10)-\mathrm{H}(10 \mathrm{~A}) \cdots \mathrm{O}(5)(\mathbf{J} 1)$ & intra & 0.9300 & 2.3080 & $2.7619(2)$ & 109.55 \\
$\mathrm{C}(1)-\mathrm{H}(1 \mathrm{~A}) \cdots \mathrm{O}(4)(\mathbf{J} 1)$ & $-1-\mathrm{x}, 2-\mathrm{y},-\mathrm{z}$ & 0.9600 & 2.5946 & $3.4547(2)$ & 149.25 \\
$\mathrm{C}(7)-\mathrm{H}(7 \mathrm{~A}) \cdots \mathrm{O}(5)(\mathbf{J 1})$ & $1-\mathrm{x}, 1-\mathrm{y},-\mathrm{z}$ & 0.9300 & 2.3911 & $3.3017(3)$ & 166.21 \\
$\mathrm{C}(18)-\mathrm{H}(18 \mathrm{~B}) \cdots \mathrm{O}(1)(\mathbf{J 1})$ & $-\mathrm{x}, 2-\mathrm{y},-\mathrm{z}$ & 0.9700 & 2.5597 & $3.4643(2)$ & 155.20 \\
$\mathrm{C}(10)-\mathrm{H}(10 \mathrm{~B}) \cdots \mathrm{O}(4)(\mathbf{J} 2)$ & intra & 0.9700 & 2.4393 & $2.843(2)$ & 104.60 \\
$\mathrm{C}(7)-\mathrm{H}(7 \mathrm{~A}) \cdots \mathrm{O}(5)(\mathbf{J} 2)$ & intra & 0.9300 & 2.5840 & $3.118(2)$ & 116.97 \\
$\mathrm{C}(2)-\mathrm{H}(2 \mathrm{~B}) \cdots \mathrm{O}(3)(\mathbf{J} 2)$ & intra & 0.9599 & 2.3090 & $2.929(3)$ & 121.63 \\
$\mathrm{C}(12)-\mathrm{H}(12 \mathrm{~A}) \cdots \mathrm{O}(1)(\mathbf{J} 2)$ & $1-\mathrm{x},-\mathrm{y}, 1-\mathrm{z}$ & 0.9804 & 2.3854 & $3.300(2)$ & 154.88 \\
$\mathrm{C}(9)-\mathrm{H}(9 \mathrm{~A}) \cdots \mathrm{O}(4)(\mathbf{J} 2)$ & $1-\mathrm{x},-1-\mathrm{y}, 1-\mathrm{z}$ & 0.9299 & 2.5723 & $3.170(2)$ & 122.45 \\
\hline
\end{tabular}

\subsection{IR Spectra}

IR spectra (KBr pellet) of $\mathbf{J 1}$ and $\mathbf{J} 2$ are similar (Figure 3). Weak absorption peaks both can be found at $2956 \mathrm{~cm}^{-1}$, which is due to the stretching vibration $\mathrm{C}-\mathrm{H}$ of the phenyl ring. Peaks at 1753 , 1716,1255 , and $1124 \mathrm{~cm}^{-1}$ (J1) and 1781, 1753, 1246, and $1124 \mathrm{~cm}^{-1}(\mathrm{~J} 2)$ are attributed to the stretching vibrations of $\mathrm{C}=\mathrm{O}$ and $\mathrm{C}-\mathrm{O}$ bands of the 1,3-dioxane ring. Five absorption peaks in $\mathbf{J} \mathbf{1}$ and four absorption peaks in $\mathrm{J} 2$ can be observed at $1600 \sim 1400 \mathrm{~cm}^{-1}$, indicating a $\mathrm{C}=\mathrm{C}$ stretching vibration of the 3,4,5-trimethoxybenzyl group and the dioxaspiro group by central $\mathrm{C}(10)$ atoms via the double bond in J1. These are in accordance with the results of the crystal structure analysis.

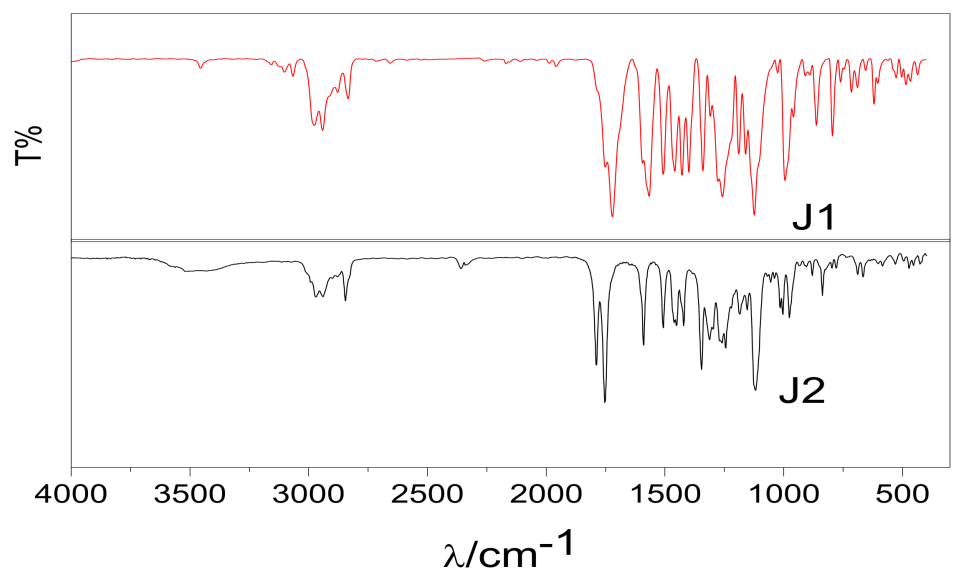

Figure 3. Infrared spectra of J1 and J2.

\section{Conclusions}

Two new compounds containing 3,4,5-trimethoxybenzyl and 6, 10-dioxaspiro groups, $\mathrm{C}_{18} \mathrm{H}_{20} \mathrm{O}_{7}$ (J1) and $\mathrm{C}_{18} \mathrm{H}_{22} \mathrm{O}_{7}(\mathbf{J} 2)$, have been designed and synthesized via two different routes. Their structures have been determined via single-crystal X-ray diffraction. The crystal structure determinations show that they are both of the triclinic, P-1 space group. The main difference is that the 3,4,5-trimethoxybenzyl group connects with the dioxaspiro group by the central $\mathrm{C}(10)$ atoms via double bond in $\mathbf{J} \mathbf{1}$ and via single bond in $\mathbf{J} \mathbf{2}$, respectively. Both compounds form three-dimensional network structures via $\mathrm{C}-\mathrm{H} \cdots \mathrm{O}$ intra- and intermolecular hydrogen bonds.

Acknowledgments: This project was supported by the Foundation of State Key Laboratory of High-Efficiency Utilization of Coal and Green (No. 2017-K29) and the Project of Shandong Province Higher Educational Science and Technology Program (No. J11LC62). 
Author Contributions: Jinhe Jiang synthesized Compounds J1 and J2. Xia Wang conceived and designed the experiments. Wulan Zeng wrote the paper.

Conflicts of Interest: The authors confirm that there are no conflicts of interest.

\section{References}

1. Chavan, S.R.; Gavale, K.S.; Khan, A.; Joshi, R.; Kumbhar, N.; Chakravarty, D.; Dhavale, D.D. Iminosugars spiro-linked with morpholine-fused 1,2,3-triazole: Synthesis, conformational analysis, glycosidase inhibitory activity, antifungal assay, and docking studies. ACS Omega 2017, 2, 7203-7218. [CrossRef]

2. Gupta, A.K.; Bharadwaj, M.; Kumar, A.; Mehrotra, R. Spiro-oxindoles as a promising class of small molecule inhibitors of p53-MDM2 interaction useful in targeted cancer therapy. Top. Curr. Chem. 2017, 375, 3. [CrossRef] [PubMed]

3. Hong, H.; Huang, L.; Teng, D.W. Aspirocyclic oxindole analogue: Synthesis and antitumor activities. Chin. Chem. Lett. 2011, 22, 1009-1012. [CrossRef]

4. Yu, B.; Shi, X.J.; Qi, P.P.; Yu, D.Q.; Liu, H.M. Design, synthesis and biological evaluation of novel steroidal spiro-oxindoles as potent antiproliferative agents. J. Steroid Biochem. Mol. Biol. 2014, 14, 121-134. [CrossRef] [PubMed]

5. Lombe, B.K.; Bruhn, T.; Feineis, D.; Mudogo, V.; Brun, R.; Bringmann, G. Antiprotozoal spirombandakamines A1 and A2, fused naphthylisoquinoline dimers from a congolese ancistrocladus. Plant. Org. Lett. 2017, 19, 6740-6743. [CrossRef] [PubMed]

6. Dandia, A.; Singh, R.; Saini, D. Ionic liquid-mediated three-component synthesis of fluorinated spiro-thiazine devivatives and their antimycobacterial and DNA cleavage activities. J. Chem. Sci. Vol. 2013, 125, 1045-1053. [CrossRef]

7. Takase, K.; Noguchi, K.; Nakano, K. Circularly polarized luminescence from chiral spiro molecules: Synthesis and optical properties of 10, 10'-Spirobi(indeno[1,2-b][1]benzothiophene) derivatives. Org. Lett. 2017, 19, 5082-5085. [CrossRef] [PubMed]

8. Majumdar, A.; Lim, C.S.; Kim, H.M.; Ghosh, K. New six-membered pH-Insensitive rhodamine spirocycle in selective sensing of $\mathrm{Cu}^{2+}$ through $\mathrm{C}-\mathrm{C}$ bond cleavage and its application in cell imaging. ACS Omega 2017, 2, 8167-8176. [CrossRef]

9. Nakagawa, T.; Ku, S.Y.; Wong, K.T.; Adachi, C. Electroluminescence based on thermally activated delayed fluorescence generated by a spirobifluorene donor-acceptor structure. Chem. Commun. 2012, 48, 9580-9582. [CrossRef] [PubMed]

10. Takizawa, S.; Kiriyama, K.; Ieki, K.; Sasai, H. A bifunctional spiro-type organocatalyst with high enantiocontrol: Application to the aza-Morita-Baylis-Hillman reactions. Chem. Commun. 2011, 47, 9227-9229. [CrossRef] [PubMed]

11. Doddi, S.; Narayanaswamy, K.; Ramakrishna, B.; Singh, S.P.; Banga, P.R. Synthesis and spectroscopic investigation of diketopyrrolopyrrole-spiropyran dyad for fluorescent switch application. J. Fluoresc. 2016, 26, 1939-1949. [CrossRef] [PubMed]

12. Yang, X.L.; Zhou, L.H.; Lv, L.; Zhao, X.; Hao, L.Y. Multi-stimuli-responsive poly(NIPA-co-HEMA-co-NVP) with spironaphthoxazine hydrogel for optical data storage application. Colloid Polym. Sci. 2016, 294, 1623-1632. [CrossRef]

13. Zeng, W.L. 5,5-[(2,4-Dichlorophenyl)methylene]bis(2,2-dimethyl-1,3dioxane-4,6-dione). Acta Cryst. 2011, 67, o1894.

14. Jiang, J.H.; Zeng, W.L. Synthesis and Crystal Structures of Two New Oxaspirocyclic Compounds. Crystals 2016, 6, 134. [CrossRef]

15. Zeng, W.L.; Liu, H.L. Synthesis and Crystal Structure of 3-((m-Tolylamino)methylene)-1,5-dioxaspiro[5.5] undecane-2,4-dione. Asian J. Chem. 2014, 26, 4356-4358.

16. Zeng, W.L.; Jiang, J.H. Synthesis and Crystal Structures of Two Novel O, N-Containing Spiro Compounds. Crystals 2016, 6, 69. [CrossRef]

17. Sheldrick, G.M. A short history of SHELX. Acta Cryst. 2008, A64, 112-122. [CrossRef] [PubMed]

(C) 2018 by the authors. Licensee MDPI, Basel, Switzerland. This article is an open access article distributed under the terms and conditions of the Creative Commons Attribution (CC BY) license (http://creativecommons.org/licenses/by/4.0/). 